\title{
PENAL REGIMES AND DISSENTERS IN THE SOVIET ORBIT
}

\author{
KAZIMIERZ GRZYBOWSKI
}

I

\section{INTRODUCTION}

The treatment of political convicts sentenced to deprivation of freedom in the socialist countries of eastern Europe has undergone an evolution that can be fully understood only against the background of the traditional treatment of political offenders which grew and developed in western and central Europe (Russia excluded) during the nineteenth and twentieth centuries, prior to World War I. This tradition, initiated by the French and American revolutions and modern penal theories developed by sociologists, led to the conclusion that political dissenters and nonconformists represent a separate class of offenders requiring special treatment and attention. ${ }^{1}$ This conviction was aided by the liberal movements which insisted on the judicial control of all aspects of the exercise of power, including the prison regimes. In the beginning of the twentieth century prisons were run according to well-defined codes. Prison administrations were controlled indirectly by the ministries of justice and directly by the district attorneys who prescribed for periodic visitation and inspection, and delegated direct control to the courts of original jurisdiction in regard to the execution of judgments. In addition, prison regimes became more directed toward rehabilitation, leading to abolition of some types of imprisonments, and segregation of prisoners according to the chances of rehabilitation, age, and recidivism. ${ }^{2}$

It was realized that it would be useless to expose political offenders to the general prison regimes in this atmosphere. In most western and central European countries, political offenders served their sentences in separate institutions, where the special regime permitted confinement without a duty to wear prison clothing. Political prisoners had access to libraries, study and writing facilities, release from compulsory work, and had the right to obtain food from outside sources. ${ }^{3}$ One aspect of the special regime applicable to political offenders was their relative freedom of correspondence and visiting privileges. ${ }^{4}$ In that age of political liberalism, it was realized that political offenders

1. See, M. Foucault, Discipline and Punish: The Birth of the Prison (A. Sheridan trans.

1977) for background on the origins of the prison.

2. Id. at $10-11,269$.

3. M. Ignatief, A Just Measure of Pain, at 120-23 (1978).

4. Id. 
often represented forces struggling for a better future government, more liberal and free, or even an outright democratic form of government-that, although in conflict with the powers that be, they were true representatives of the aspirations of the broad social masses.

\section{The Liberal Age and Soviet Dissent}

Before we proceed with the main subject of this article, it is necessary to note an important difference between the dissenter of the age of liberalism and the dissenter who is the product of the current conditions prevailing in the Soviet socialist countries. The pre-World War I dissenter wanted to change the existing order. He/she was active politically in efforts to replace the existing form of government or in efforts to win recognition of the rights of social, national, ethnic, or religious minorities. Today, Soviet dissenters insist on the enforcement of the principles of the existing constitutional order in the socialist countries, such as freedom of speech, the press, religion; he/she insists on the right to criticize the actions of the government and its economic and social policies. The Soviet socialist dissenter is the product of the unfulfilled promise that the government and power belong to the people. In contrast with the liberal age dissenter, who desired change, the Soviet dissenter desires that relations between government and the people be governed by the existing law. ${ }^{5}$

The writings of the leading Soviet dissenters quarrel little with the letter and spirit of the laws or even with the totalitarian character of the Soviet state. Of the leading dissenters, only Solzhenitsyn desires modification of some features of the Soviet economic order: he sees Russia's future in the emergence of the peasant farming society. Medvedev and Sakharov stress the need to change both the internal and external policies of the Soviet Union that are characteristic of the continuing philosophies of the Stalin regime to assure a freer style of life; important issues are: imperialism, suppression of freedom, and hostility towards nonsocialist regimes, which, in their view, have been able to assure a better life for the working man. Acceptance of the Soviet regime goes so far that dissenters accept and even uphold the leading role of the Party. ${ }^{6}$ In effect, their program is modest and can be put into practice without affecting the basic features of the Soviet order. On the whole, the dissenters are in conflict not with the institutions but with Soviet government policies. The quarrel of the socialist regimes in eastern Europe is

5. See, V. Chalidze, To Defend These Rights (G. Daniels trans. 1974); Lecture by Pavel Litvinov, The Human Rights Movement in the USSR, reprinted in 4 INDEx on CensorshIP, Spring 1975 , at $11-15$.

6. See, Sakharov, Medvedev and Turchin, Appeal For a Gradual Democratization in Samizdat: Voices of The Soviet Opposition 399-412 (G. Saunders ed., M. Vogt trans. 1974). 
not so much with the dissenters' struggle for the reforms as with the demand for the realization of human rights, which are, as a matter of fact, guaranteed generously in the constitutions of eastern European countries. ${ }^{7}$

Some of the attitudes of the eastern European regimes toward the demands and claims of the dissenters may be discerned from the tone of the eastern European government press (there is no other) in its reports on the proceedings of the Belgrade conference on the Helsinki Declaration. A Soviet paper rejected the charge that the Soviet regime pays no respect to the realization of the principles of the Helsinki Act by stating that, "an honest Soviet citizen, who does not meddle in the business of government or the Party, has nothing to fear from the Soviet state,"8 thus acknowledging the fact that government business is of no concern to the citizen. Only when a distinction is drawn between the dissenter of the liberal age and the Soviet dissenter may we understand the rationale of the penal regime applied to the dissenters in socialist societies.

\section{Organization of Political Police}

The present eastern European situation still displays the techniques used in the Soviet Union during the Civil War to exterminate and stamp out political movements hostile to the Communist regime established by the revolution. Its most important feature was the creation of special agencies, which were given the right to impose penalties without trial for political unorthodoxy and generally to apply various measures to remove class enemies from Russian society. The name of the agency was changed from the Extraordinary Commission, established in 1917, to the present Committee for State Security. This agency has always been endowed with broad, undefined powers to arrest, imprison, and put to death all who are or could be considered enemies of the regime. From the beginning it had the right to place any people or social groups that were a threat to the regime in confinement or in forced labor camps without trial; the threats ranged from opposition within and from without the Communist Party to those guilty of ordinary and political crimes or violations of the social order and juvenile deliquency. The latter category included entire minority groups such as Balts, Kalmucks, Crimean Tartars,

7. Appeal to World Public Opinion, The London Times, Jan. 13, 1968, at 8, col. 1, reprinted in 4 INDEX ON Censorship, Spring 1975, at 7-8; Solzhenitsyn, Letter to the Congress of the Writers of the Soziet Union, Sept. 9, 1967, in 3 Sobranie Dokumentov Samizdata A.S. 175 (1975); A. Solzhenitsyn, LetTer to the Soviet Leaders (H. Sternberg trans. 1974), reprinted in In QUeST of Justice 245-50 (A. Brumberg ed. 1974); A. Sakharov, Progress, Coexistence and IntelLectual Freedom (N.Y. Times trans. 1968); Medvedev, The Essay of Our Day, in 5 Sobranie Dokumentov Samizdata A.S. 306 (1973).

8. Pravda, July 1, 1972. 
Volga Germans, and Poles found living in the Soviet-occupied territories. ${ }^{9}$ Some insight into the operation of these agencies may be gleaned from the order issued by the Extraordinary Commission, which stated, ". . . that the law gave [it] the ... power to imprison by an administrative procedure, those ... whom any court, even the most severe, would . . . acquit."10

The regime, which was introduced in eastern and central Europe, occupied by Soviet armies as a consequence of the 1945 German defeat, has survived in its essential form until the present. Its basic feature was the creation of exceptional police powers, controlling prisons, frontier guards, intelligence and counter-intelligence, and administration of forced labor camps. In theory, the police force and its various internal and external activities are controlled by the Ministry of Interior. In fact, ministries of interior are simply heads of the police organizations; therefore, control and supervision of prisons and penal regimes by the courts and ministries of justice were abolished.

The use of extensive police powers as the main instrument of social control survived until Stalin's death, when some of the more extravagant forms of the police terror were removed. While the first move was to restrict powers of the police in regard to the control of public life of these countries, it took some time before the police control of the prisons and labor camps was either removed or substantially restricted.

\section{Legal Regimes of Penal Institutions}

Since the late 1960s, the prison penal regimes of eastern Europe were based on regular legislation passed by the legislatures. Thus, one of the serious shortcomings prevailing until a few years ago, regulation of penal regimes by legislative acts issued by the police authorities, was removed. Bulgaria adopted a law on the execution of penalties in $1969,{ }^{11}$ which was amended in $1974 .{ }^{12}$ Czechoslovakia adopted a similar law in $1955 .{ }^{13}$ In Yugoslavia, execution of penalties is regulated in several laws adopted in the period between 1961 and 1969. ${ }^{14}$ East Germany adopted a law in 1968 on the execution of penalties and the resocialization of convicts. ${ }^{15}$ In Poland, a code on the execution of penalties was enacted in $1969 .{ }^{16}$ A law on the execution of punishments went

\footnotetext{
9. Gsovski, The Soviet Courts: Their Aims and Functioning, in 1 Government, Law and Courts in the Soviet Union and Eastern Europe 565 (K. Grzybowski \& V. Gsovski eds. 1959).

10. Id. at 568 .

11. Bulgarian Law Gazette (1967).

12. Bulgarian Law Gazette (1974).

13. Czechoslovakian Law Gazette (1965); Czechoslovakian Law Gazette (1973).

14. Yugoslavian Law Gazette (1970).

15. I GBI. DDR 109 (1968).

16. Polish Law Gazette, No. 13 (1969).
} 
into force in Rumania in $1969 .{ }^{17}$ Hungary adopted a law on the execution of punishments and temporary detention in 1965, which was amended in $1971 .^{18}$ In the Soviet Union, execution of penalties is regulated, as to its basic principles, by the federal law on correctional labor ${ }^{19}$ (this being the main form of punishment). Specific provisions are enacted by the several union republics in codes modeled after the law adopted by the Russian Soviet Federalist Socialist Republic in $1970 .^{20}$

A vast majority of socialist countries have returned the administration of prisons to their ministries of justice (Bulgaria, Czechoslovakia, Yugoslavia, Hungary, and Poland). The rest (Soviet Union, Rumania, and East Germany) continue to administer their penal institutions by the ministries of the interior, which are also in charge of police organizations. Usually administration of penal institutions is under a separate agency, which in addition to various categories of custodial, administrative, and medical personnel, employ large numbers of specialists in re-education and resocialization. ${ }^{21}$

We cannot discuss comprehensively here the regimes in socialist prisons. Let it suffice that, although on the whole (the exception being Yugoslavia), there are no distinctions in forms of the penalty of deprivation of freedom, in effect, the regimes applied to various categories of prisoners differ fundamentally. The classification of prisoners into various groups who serve their terms of deprivation of freedom under regimes of treatment varying from light to severe depends on the prisoners' social danger in the Communist countries; the severity of the regime is determined by the court imposing the penalty. ${ }^{22}$ Legislation of the socialist countries assigns routinely the most severe regime of the deprivation of freedom to those guilty of crimes against the state, theft of government property, sabotage, subversion, treason, espionage, murder, armed robbery, and recidivists who have already suffered a penalty of deprivation of freedom. In short, dissenters and political offenders are placed in a category with the most dangerous criminals. They serve their punishment in special institutions under the most severe regime; their rights in regard to correspondence, visitors, receiving parcels, and purchasing goods from prison shops are restricted severely. In the Soviet Union, penal institutions in which dissenters suffer their punishments are usually found in the remote regions of the country which have harsh climatic and working conditions. ${ }^{23}$

17. Rumanian Law Gazette (1969).

18. Hungarian Law Gazette (1971).

19. Vedomosti SSSR, no. 29, item 247 (1969) (amended Apr. 26, 1973, Feb. 8, 1977 \& Sept.

7,1977 ) reprinted in The Soviet Legal SyStem 701 (W. Butler ed. \& trans. 1978).

20. Vedomosti RSFSR (1970); Amnesty International, Prisoners of Conscience in the

USSR 36 (1976).

21. See, e.g., PRISONERS OF Conscience IN THE USSR, supra note 20, at 36-42, 71-80.

22. See, e.g., id. at 45 .

23. Id. at $48-53$. 
The spouses of long-term convicts have the right to sue for divorce, which is granted almost routinely, with court decrees (custody of children and disposal of property rights held jointly) generally favoring the suing spouse. ${ }^{24}$ Conviction for a political offense makes it impossible to return to one's occupation, profession, or mode of life, and in most cases, makes it impossible to return to the previous place of residence. Employment and place of residence after release are at the discretion of the administrative authorities. In the Soviet Union especially, the right to settle in cities of the first category, where opportunities for intellectual work are centered exclusively, requires a permit from the administrative authority and depends on obtaining employment in an institution or enterprise run by one of the ministries of the government. In fact, conviction of a dissenter under one of the extremely vague provisions of the socialist criminal codes amounts to a permanent banishment of the offender from the environment in which he lived before coming into conflict with the socialist state. ${ }^{25}$

Socialist legislation on the execution of prison sentences in eastern Europe routinely contains high-sounding phraseology regarding the rights of convicts-for example, Soviet legislation states that "persons serving prison sentences . . retain duties and rights of the citizens of the U.S.S.R." ${ }^{26}$ However, the law is silent when it comes to specific enumeration of these rights and their defense. The prisoner has no recourse to courts nor can he/she ask for legal assistance. The only remedy at his/her disposal is a complaint to the prison administration.

\section{Conclusion}

The position of the dissenters in the eastern European countries under the Communist regimes is influenced by the level of consciousness of the general public in regard to the value of the legal guarantees of civil rights. In some countries, broad masses of the population feel a bond with the intellectuals in the professions, literature, the arts, science, and journalism, assuring them a comparatively high degree of immunity from government repressions. The current Polish situation is characterized by the fact that intellectuals support the demands of the workers, who in turn exert pressure on the government and the party to defend intellectuals' freedom to speak in their de-

\footnotetext{
24. See, Vedomosti SSSR, no. 27, item 241 (1968), reprinted in The Soviet Legal System, supra note 19, at 455 .

25. Numerous cases exist evidencing the harsh effects convictions for political crimes have on the continuation of previous work, mode of life and residence after release. Many of these cases are documented in Amnesty International, A Chronicle of Current Events.

26. Supra note 19 .
} 
fense. ${ }^{27}$ This fact offers a fragile and uncertain assurance that the regime will respect the law and common decency. Certainly, the 1968 effort to liberalize the regime in Czechoslovakia has failed, suppressed by Soviet military invasion.

It seems that there is little hope for a dramatic change with regard to basic civil rights in the Soviet Union, primarily because the Soviet public has little understanding of the rights, value, and importance of individual existence. One may quote many examples that indicate lack of the basic aspects of the rule of law among the Soviet population or the enormous bureaucracy entrenched in the administrative apparatus, economic management of the country, professional organizations, and educational and cultural institutions. ${ }^{28} \mathbf{R e}$ ports from Soviet courts suggest frequently that judges, prosecutors, and the general public have little understanding of such notions as presumption of innocence, of the rights of the defendant, of the role of defending attorneys, or of the principle of objectivity and impartiality, which should control disposal of political cases. Certainly these examples suggest that neither the Soviet legal community and political leaders of the country nor the public at large are committed to the idea of legality and due process of law as they are understood in the open societies. ${ }^{29}$

Let me end this article by recounting a case of a literature teacher in a Soviet high school. The teacher, Gerlina, signed a letter concerning the trial of a group of dissenters protesting the manner in which they were treated in court and in the related press reports. Gerlina was called to a meeting of the teachers trade union and was charged with breaking her moral obligations with regard to the ideological values that she must convey in teaching her Russian literature course. She replied that she was concerned with the authority of law in Soviet courts and that her letter, addressed to Soviet higher authorities, simply asked for a review of the case. Her explanation was interrupted by a teacher of mathematics, who questioned whether the enemies of the Soviet Union must be judged according to law. "Not only they," answered Gerlina, "but even war criminals must be judged according to it." The mathematics teacher restated his position, "We cannot judge such criminals according to justice. They would be declared not guilty." The meeting was almost unanimous in declaring that Gerlina was unfit to teach in the Soviet school system. ${ }^{30}$

27. See, Smolar, The Protest Movement in Poland, 6 INDEx on CENsorship, March/April 1977, at $8-12$.

28. K. Grzybowski, Freedom of Expression and Dissent in the Soviet Union (1972).

29. Economic Crimes in the Soviet Union, $5 \mathrm{~J}$. INT'L Comm. JURISTS 1-48 (1964).

30. 7 Sobranie Dokumentov Samizdata A.S. 478 (1973). 